IJMS 16 (1), 75-96 (2009)

\title{
DIMENSI PELAPORAN KEWANGAN MENERUSI INTERNET
}

\author{
MOHD NOOR AZLI ALI KHAN \\ Fakulti Pengurusan dan Pembangunan Sumber Manusia \\ Universiti Teknologi Malaysia \\ NOOR AZIZI BIN ISMAIL \\ College of Business \\ Universiti Utara Malaysia
}

\begin{abstract}
ABSTRAK
Revolusi penggunaan internet menyediakan pengurusan korporat dengan kaedah yang unik bagi komunikasi maklumat korporat, termasuk maklumat kewangan, terus kepada para pelabur, bakal pelabur dan para pemegang saham. Konsisten dengan kemajuan internet sebagai alat komunikasi yang murah tetapi berpengaruh, pendedahan maklumat kewangan menerusi internet menjadi subjek kajian yang semakin popular. Banyak kajian telah dijalankan terhadap keberkesanan, kaedah dan kualiti Pelaporan Kewangan Menerusi Internet (PKMI) sepanjang dekad yang lalu. Bagaimanapun, kebanyakan kajian awal PKMI ini lebih bersifat deskriptif dan penerokaan. Justeru, kajian tersebut tidak mampu menerangkan item yang dapat mewakili tahap PKMI. Walaupun kebanyakan kajian mengakui kebenaran bahawa proksi yang bersesuaian seperti indeks pelaporan boleh digunakan bagi pemahaman mendalam mengenai kecanggihan maklumat yang dilaporkan oleh syarikat, namun masih sedikit usaha yang dilakukan untuk membina indeks tersebut. Daripada kajian yang sedikit ini, penggunaan dimensi bagi mewakili PKMI tidak konsisten dalam kalangan penyelidik. Perbezaan ini menyumbang kepada perbezaan dapatan kajian dan seterusnya gagal menerangkan dengan jelas faktor yang mempengaruhi tingkah laku PKMI. Oleh itu, artikel ini membincangkan isu berkaitan indeks pelaporan melalui sorotan literatur secara komprehensif dan kemudiannya mencadangkan dimensi yang bersesuaian bagi indeks pelaporan untuk mewakili PKMI.
\end{abstract}

Kata kunci: Dimensi; indeks pelaporan dan pelaporan kewangan menerusi internet. 


\begin{abstract}
Purpose - This paper aims to address the issue of internet financial reporting (IFR) index, by carefully reviewing existing literature relating to the topic, and then suggests a suitable dimension of disclosure index to represent IFR.

Design/Methodology/Approach - The study was dependent on an extensive review of the literature of IFR.

Findings - Many have investigated the extent, mode and quality of IFR over the last decade. Most of early IFR research is descriptive and exploratory in nature, thus unable to explain the item to represent the level of IFR. Furthermore, while many have conceded that a suitable proxy such as an index of disclosure can be used to gain insight into the sophistication of information disclosed by companies, to date, very few attempts have been made to develop such index. Of these few studies, the dimensions used to represent IFR are inconsistent among the researchers. These differences contribute to the variations in the findings and thus are unable to clearly explain factors influencing the behaviour of the IFR. Based on extensive literature review, we can conclude that the level of IFR can be categorised into two dimensions, which are content and presentation.
\end{abstract}

Originality/Value - The paper provides a basis for mapping existing and future studies on IFR and constructing scenarios of future studies in this area.

Keywords - Dimension; content; presentation; index; internet financial reporting.

Paper type - Conceptual paper.

\title{
PENGENALAN
}

Maklumat merupakan elemen kritikal kepada fungsi pasaran modal (Lee, 1987; Saudagaran \& Diga, 1997). Maklumat, terutamanya maklumat kewangan, bukan hanya membantu mengurangkan ketidaktentuan dalam keputusan pelaburan dan pengagihan sumber secara efisyen, tetapi dapat meningkatkan ketelusan urusan korporat dengan para pelabur dan pemegang saham yang lain (Healy \& Palepu, 2001). Banyak syarikat yang menggunakan laman web World Wide Web (WWW) sebagai satu platform untuk membentangkan data kewangan, terutamanya laporan tahunan korporat, pangkalan data berkenaan siaran akhbar dan maklumat lain berkaitan syarikat kepada para pemegang saham (Deller 
Stubenrath \& Weber, 1999; Celik Ecer \& Karabacak, 2006). Maklumat tersebut boleh dipertimbangkan oleh pihak yang berkepentingan dalam membuat keputusan pelaburan dan keputusan perniagaan yang lain (FASB, 2000). Pelaporan Internet menjadi satu fenomena yang begitu cepat berkembang (Ashbaugh Johnstone \& Warfield 1999; Oyelere Laswad \& Fisher, 2003). Oleh itu, kajian mengenai perubahan keadaan bagi pelaporan kewangan adalah penting kerana Internet menjadi medium komunikasi yang penting (Xiao Jones \& Lymer, 2002).

Penelitian yang komprehensif terhadap literatur berkaitan indeks pelaporan menunjukkan bahawa para penyelidik menggunakan dimensi yang berbeza-beza untuk menggambarkan indeks pelaporan kewangan menerusi Internet (selepas ini dikenali sebagai PKMI). Perbezaan penggunaan dimensi menyumbang kepada perbezaan dapatan kajian yang menyebabkan ketidakupayaan menerangkan dengan jelas fenomena yang berlaku dan apakah faktor penentu yang mempengaruhi praktis PKMI. Oleh itu, dimensi bagi indeks PKMI adalah agenda penting dan menarik untuk diselidiki kerana pelaporan merupakan suatu konsep yang begitu abstrak yang tidak boleh diukur secara terus. Indeks yang lebih komprehensif dan holistik mengandungi beberapa dimensi amat diperlukan. Diharap dengan penelitian terhadap dimensi tersebut dapat membantu penyelidik untuk menjelaskan dengan lebih baik mengenai praktis bagi PKMI dan faktor penentu yang mempengaruhi praktis tersebut.

Artikel ini disusun seperti berikut: definisi PKMI dijelaskan dalam bahagian kedua. Perbincangan dalam bahagian ketiga merujuk kepada kelebihan dan penyelidikan PKMI. Manakala, bahagian seterusnya membincangkan penggunaan indeks pelaporan dan diakhiri dengan rumusan dan implikasi kajian.

\section{DEFINISI}

Terdapat pelbagai definisi bagi PKMI yang digunakan dalam kalangan para penyelidik (Ashbaugh et al., 1999; Craven \& Marston, 1999; FASB, 2000; Oyelere et al., 2003; Rosli, Mudzamir \& Amdan, 2003; Mohamed Hisham \& Hafiz-Majdi, 2005; Chan \& Wickramasinghe, 2006; Momany \& Al-Shorman, 2006). Menurut Ashbaugh et al. (1999), sesebuah syarikat dikatakan melaksanakan PKMI sekiranya: (1) laman web syarikat digunakan untuk melaporkan penyata kewangan yang komprehensif termasuk nota kaki dan laporan audit; (2) mempunyai sambungan ke 
laporan tahunan syarikat melalui Internet atau; (3) satu sambungan ke sistem U.S. Security and Exchange Commission's (SEC) dan Electronic Data Gathering, Analysis and Retrieval (EDGAR). Craven dan Marston (1999) pula menggunakan laporan tahunan yang terperinci dan sebahagian atau ringkasan laporan tahunan sebagai pengukuran bagi pelaporan maklumat kewangan menerusi Internet. Manakala, FASB (2000) mendefinisikan praktis menerusi Internet sebagai kaedah bagi operasi, teknik, dan praktis lain yang direka bagi memaksimumkan penggunaan keupayaan laman web untuk menyalurkan maklumat perniagaan.

Oyelere et al. (2003), Rosli et al. (2003), dan Momany dan Al-Shorman (2006) menjelaskan bahawa syarikat yang mengamalkan PKMI merangkumi syarikat yang melaporkan: (1) penyata kewangan secara menyeluruh, termasuk nota kaki; (2) sebahagian daripada penyata kewangan dan/atau; (3) maklumat kewangan penting seperti ringkasan penyata kewangan dalam laman web syarikat. Mohamed Hisham dan Hafiz-Majdi (2005) pula mendefinisikan syarikat yang mengamalkan PKMI sebagai firma yang memuatkan laporan tahunan terkini atau yang menyediakan pautan kepada laman web Bursa Saham Kuala Lumpur (BSKL). Manakala, Chan dan Wickramasinghe (2006) mentakrifkan syarikat yang mengamalkan PKMI sebagai syarikat yang melaporkan penyata kewangan yang komprehensif (termasuk nota kaki dan laporan tahunan) atau mempunyai sambungan ke laporan tahunan syarikat menerusi Internet.

Sebagai kesimpulan, terdapat pelbagai definisi yang digunakan dalam kalangan penyelidik untuk mewakili maksud PKMI. Bagaimanapun, kebanyakan penyelidik memasukkan set komprehensif penyata kewangan dan penyata kewangan penting yang dipetik daripada laporan tahunan bagi melayakkan sesebuah syarikat dikategorikan sebagai syarikat yang mempraktiskan PKMI.

\section{KELEBIHAN DAN PENYELIDIKAN PKMI}

Pertamanya, bahagian ini membincangkan secara ringkas mengenai potensi yang merangsang syarikat menyediakan maklumat kewangan menerusi Internet. Di antara kelebihan yang diperoleh oleh syarikat yang memperkenalkan pelaporan dalam talian menerusi Internet ialah: pengurangan kos yang terlibat dan masa yang diperlukan bagi menyebarkan maklumat kepada para pengguna; komunikasi dengan penguna maklumat yang tidak dapat dikenal pasti sebelum ini; 
penambahan kepada praktis pendedahan secara tradisional; peningkatan dari segi jenis maklumat yang didedahkan; penambahbaikan untuk mencapai laman web syarikat kecil yang mempunyai pelabur yang berpotensi (Lymer, 1999; FASB, 2000; Debreceny Gray \& Rahman, 2002; Mohamed Hisham \& Hafiz-Majdi, 2005). Selain daripada faedah-faedah yang dinyatakan di atas, syarikat turut menunjukkan minat dalam penggunaan teknologi Internet bagi tujuan pemasaran, jualan (Lymer, 1999) dan pelaporan kewangan (Xiao, Jones \& Lymer 2002), strategi penyebaran maklumat bagi bidang perbankan Islam (Mokhtar \& Azhari, 2004) dan imej korporat (Bonson \& Escobar, 2006).

Selaras dengan perkembangan Internet dan penggunaannya dalam pelaporan kewangan, kajian-kajian khususnya berkaitan PKMI mula diterbitkan pada pertengahan tahun 1990-an (Allam \& Lymer, 2003). Bagaimanapun, kajian-kajian awal berkaitan PKMI adalah bersifat deskriptif. Fokus utama kajian berkisar kepada kewujudan laman web dalam kalangan syarikat yang tersenarai di Bursa Saham dan sama ada syarikat tersebut ada menyediakan maklumat tertentu di dalam laman web syarikat (Petravick \& Gillett, 1996; Louwers, Pasework \& Typpo 1996; Lymer, 1997; Flynn \& Gowthorpe, 1997; Gray \& Debreceny, 1997; Petravick \& Gillett, 1998). Selain itu, isu PKMI turut menarik minat badan-badan profesional perakaunan untuk membuat kajian berkaitan PKMI, antaranya Institute of Chartered Accountants in England and Wales (ICAEW, 1998; ICAEW, 2004), International Accounting Standards Committee (IASC, 1999), Canadian Institute of Chartered Accountants (CICA, 1999), dan Financial Accounting Standards Board (FASB, 2000; FASB 2001).

Skop kajian PKMI turut berubah dan berkembang selaras dengan perkembangan teknologi Internet. Contohnya, paparan spesifik bagi pelaporan kewangan dalam talian, dan impaknya terhadap entiti pelaporan dan para pengguna, menjadi fokus bagi laporan yang diterbitkan (William \& Pei, 1999; Hodge, 2001; Beattie \& Pratt, 2001; Ettredge, Richoudson \& Scholz, 2001b). Selain daripada itu, penyelidikan PKMI turut mengkaji pembangunan semasa pelaporan dalam talian (Allam \& Lymer, 2003). Penyelidik PKMI juga terlibat dalam mengkaji sejauh mana jenis maklumat yang didedahkan menerusi Internet dilaksanakan. Beberapa kajian turut menambah skop kajian bagi mengkaji atribut PKMI dengan lebih terperinci (Lymer \& Tallberg, 1997; Marston \& Leow, 1998; Heldin, 1999; Pirchegger \& Wagenhofer, 1999; Ashbaugh et al., 1999; Deller et al., 1999; Gowthorpe, 2000; Ettredge et al., 
2001a; Oyelere, Laswadi \& Fisher 2003). Banyak kajian yang dijalankan bagi mengkaji faktor penentu yang mempengaruhi praktis PKMI seperti saiz syarikat, keberuntungan, leveraj, firma audit, jenis industri, status penyenaraian, kecairan, pertumbuhan, prestasi, risiko sistematik, tahap teknologi dan struktur pemilikan.

Secara ringkasnya, walaupun banyak kajian berkaitan PKMI yang telah dijalankan sepanjang dua dekad yang lalu, hanya sedikit sahaja memberi fokus kepada pembinaan indeks pelaporan bagi menerangkan fenomena PKMI ini dengan lebih baik. Penggunaan indeks pelaporan ini penting bagi tujuan perbandingan amalan PKMI antara syarikat, industri dan negara. Selain itu, bidang penyelidikan PKMI lebih tertumpu kepada negara maju seperti Amerika Syarikat, Britian dan Jerman. Terdapat sedikit kajian yang dilakukan ke atas negara yang sedang membangun (Davey \& Homkajohn, 2004). Malahan, kajian praktis PKMI di Malaysia masih berada di peringkat permulaan (Mohamed Hisham \& HafizMajdi, 2005). Secara ringkasnya, penyelidikan PKMI boleh dibahagikan kepada tiga kategori: kajian satu negara, kajian beberapa negara dan kajian peringkat antarabangsa (Celik, Ecer \& Karabacak 2006). Oleh yang demikian, penulisan artikel ini cuba untuk menyumbang kepada literatur berkaitan PKMI yang sedia ada dengan meneliti dan menyemak dimensi yang digunakan bagi mewakili PKMI.

\section{PENGGUNAAN INDEKS PELAPORAN}

Penelitian terhadap kajian lalu menghasilkan usaha untuk mengkaji tahap PKMI menggunakan indeks pelaporan. Ketika artikel ini ditulis sebanyak 23 buah artikel dirujuk, disemak dan diteliti. Hasil tinjauan literatur menunjukkan bahawa terdapat tujuh dimensi utama yang kerap digunakan oleh para penyelidik. Jadual 1 menunjukkan dimensi yang digunakan dalam membangunkan indeks pelaporan berkaitan PKMI. Di antara dimensi yang sering digunakan untuk mengukur tahap PKMI ialah kandungan dan pembentangan; kandungan, pemasaan, teknologi dan sokongan pengguna. Dimensi yang digunakan untuk mengukur tahap PKMI bagaimanapun adalah tidak konsisten dalam kalangan penyelidik. Perbezaan ini menyumbang kepada perbezaan dapatan kajian berkaitan faktor yang mempengaruhi amalan PKMI dalam kalangan syarikat. Oleh itu, dapatan kajian tersebut tidak berupaya untuk menerangkan dengan jelas faktor penentu yang mempengaruhi amalan PKMI dalam kalangan korporat. 
Jadual 1: Pengklasifikasian Dimensi

\begin{tabular}{|c|c|c|}
\hline Bil. & Klasifikasi & Penyelidik (Tahun) \\
\hline 1 & Kandungan dan Pembentangan & $\begin{array}{l}\text { IASC (1999), Debreceny et al. (2002), Trabelsi et al. } \\
\text { (2002), Marston dan Polei (2004), Xiao et al. (2004), } \\
\text { Bonson dan Escobar (2006), Spanos (2006) }\end{array}$ \\
\hline 2 & $\begin{array}{l}\text { Kandungan, Pemasaan, Teknologi dan So- } \\
\text { kongan Pengguna }\end{array}$ & $\begin{array}{l}\text { Pirchegger dan Wagenhofer (1999), Lybaert (2002), } \\
\text { Davey dan Homkajohn (2004), Pervan (2006), } \\
\text { Chan dan Wickramasinghe (2006) }\end{array}$ \\
\hline 3 & $\begin{array}{l}\text { Atribut Am, Atribut Hubungan dengan } \\
\text { Pelabur/Maklumat Kewangan, Atribut } \\
\text { Laporan Tahunan dan Lain-lain Atribut }\end{array}$ & FASB (2000), Khadaroo (2005), Celik et al. (2006) \\
\hline 4 & Hubungan dengan Pelabur & $\begin{array}{l}\text { Fathilatul Zakimi dan Md Suhaimi (2005), Deller } \\
\text { et al. (1999) }\end{array}$ \\
\hline 5 & Pendedahan: Keperluan dan Sukarela & $\begin{array}{l}\text { Ettredge } \text { et al. (2002), Mendes-da-Silva dan Chris- } \\
\text { tensen (2004) }\end{array}$ \\
\hline 6 & Atribut Am dan Atribut Kewangan & Allam dan Lymer (2003), Lodhia et al. (2004) \\
\hline 7 & $\begin{array}{l}\text { Maklumat Perakaunan dan Maklumat Ke- } \\
\text { wangan }\end{array}$ & Ettredge et al. (2001a) \\
\hline
\end{tabular}

Jadual 2 menunjukkan penyelidikan berkaitan dimensi dan item bagi PKMI, penyelidik dan tahun hasil kajian diterbitkan, skop kajian, bilangan item dalam instrumen kajian dan dimensi yang digunakan bagi mewakili indeks PKMI. Artikel yang diteliti dan disemak disusun mengikut kajian terkini bagi mengenal pasti arah aliran kajian berasaskan masa. Usaha pertama membangunkan indeks pelaporan dilakukan pada 1999 atas inisiatif Pirchegger dan Wagenhofer. Idea Pirchegger dan Wagenhofer (1999) kemudiannya digunakan oleh penyelidik lain (Lybaert, 2002; Davey \& Homkajohn, 2004). Indeks pelaporan tersebut turut digunakan oleh Chan dan Wickramasinghe (2006), Pervan (2006), Khan (2006), dan Sriram dan Laksmana (2006). Bagaimanapun, bilangan item yang digunakan untuk membangunkan indeks PKMI berbeza-beza dalam kalangan penyelidik bermula daripada 14 item (Fathilatul Zakimi \& Md Suhaimi, 2005) hingga 164 item (Celik et al., 2006).

Keterangan setiap dimensi yang digunakan bagi mewakili PKMI dinyatakan dalam lajur 6 dalam Jadual 2. Daripada keseluruhan dimensi, pengkelasan yang dibuat oleh Pirchegger dan Wagenhofer (1999) merupakan antara dimensi yang kerap digunakan oleh para penyelidik (Lybaert, 2002; Davey \& Homkajohn, 2004; Pervan, 2006; Chan \& Wickramasinghe, 2006). Berdasarkan penelitian terhadap indeks PKMI, Pirchegger dan Wagenhofer (1999) mengkategorikan katalog bagi kriteria untuk menilai laman web syarikat kepada empat dimensi utama, iaitu: kandungan, pemasaan, teknologi dan sokongan pengguna. Dimensi kandungan dan pembentangan pula adalah dimensi yang paling popular dan kerap digunakan oleh penyelidik dalam bidang berkaitan PKMI (IASC, 1999; Debreceny et al., 2002; Marston \& Polei, 2004; Trabelsi, Labelle \& Laurin 2004; Xiao et al., 2004; Spanos, 2006; Bonson \& Escobar, 2006). Dimensi ini pada asalnya digunakan dalam kajian FASB (2000). 


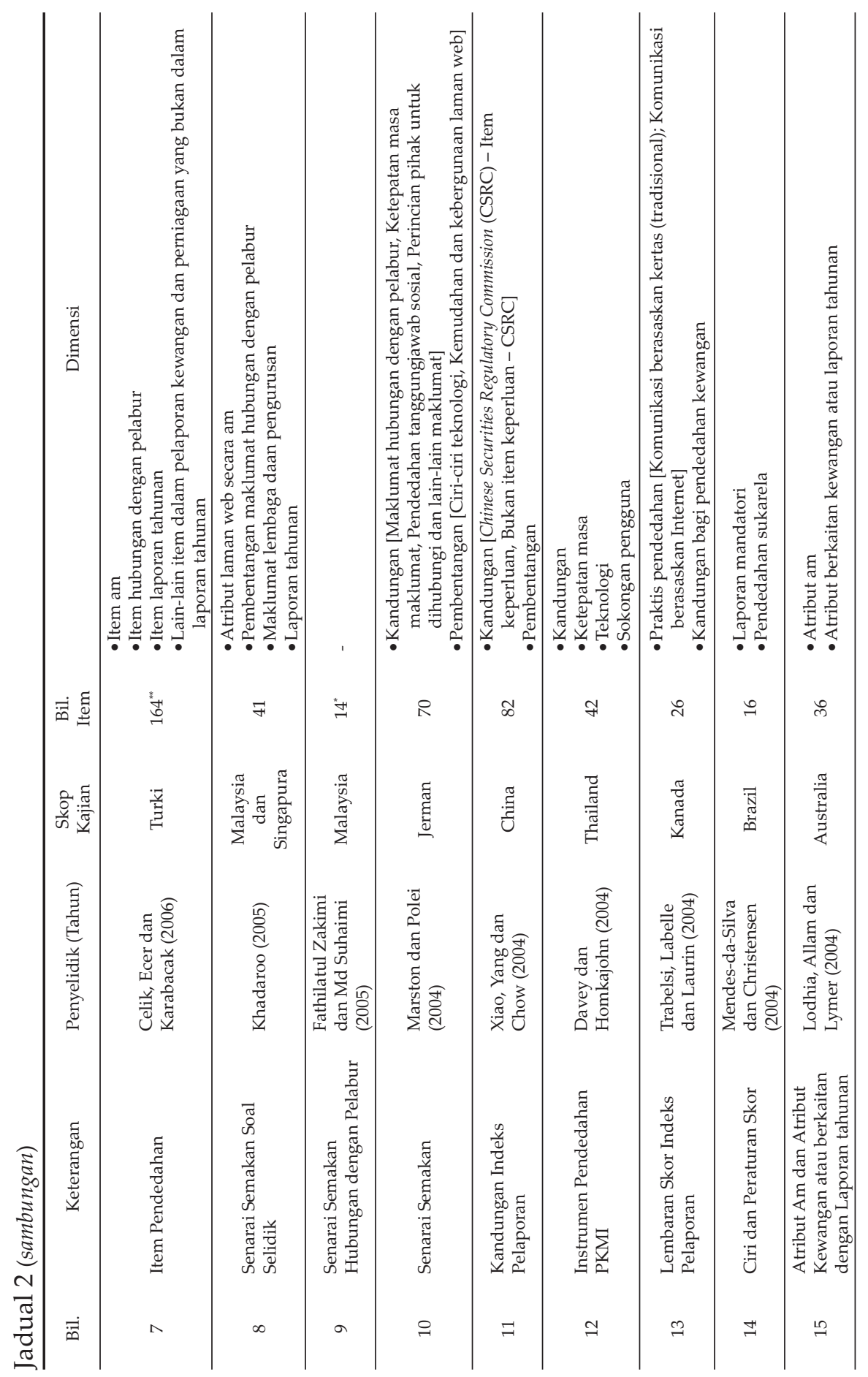

IJMS 16 (1), 75-96 (2009) 83 


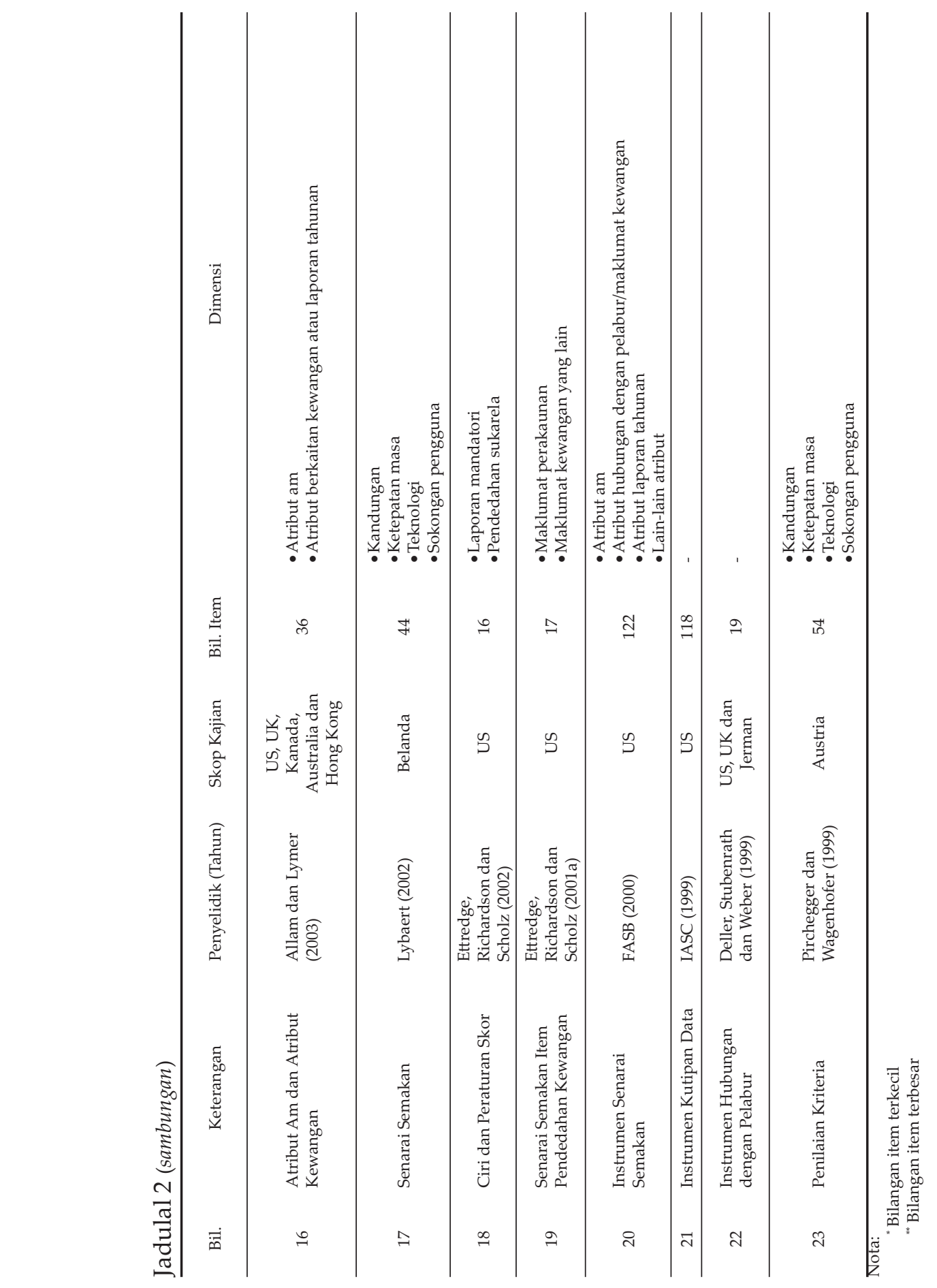

84 IJMS 16 (1), 75-96 (2009) 
Menurut Debreceny et al. (2002), terdapat beberapa kajian yang menyediakan kerangka kerja untuk mengillustrasikan dimensi bagi PKMI (IASC, 1999; Trites, 1999; Ashbaugh et al., 1999; FASB, 2000). IASC (1999, 48) membahagikan PKMI kepada tiga peringkat. Peringkat pertama, syarikat menggunakan Internet hanya sebagai saluran pengedaran lain sebagai alternatif kepada laporan tahunan bercetak. Pada peringkat kedua, syarikat beralih untuk melaporkan maklumat syarikat dalam bentuk semakan lewa (browser) dan enjin pencarian laman web yang boleh digunakan pada setiap masa. Akhirnya, pada peringkat ketiga, syarikat menyediakan bukan hanya maklumat piawai seperti yang ada dalam laporan tahunan bercetak, tetapi turut menyediakan maklumat tambahan dan kemudahan interaktif untuk menganalisis maklumat.

Trites (1999) pula mengenal pasti bahawa impak pelaporan dalam talian secara elektronik adalah terhadap kandungan, pemasaan, dan format bagi maklumat kewangan. Paparan merupakan elemen penting bagi PKMI dan berfungsi sepanjang masa tanpa batas sempadan. Beliau menambah lagi bahawa penggunaan hiperpaut bagi pelaporan kewangan berasaskan laman web berkemungkinan mengaburkan sempadan antara maklumat kewangan (yang berkemungkinan disediakan mengikut piawaian yang spesifik dan diaudit) dan maklumat korporat yang lain (yang tidak disediakan mengikut piawaian yang spesifik dan tidak diaudit).

FASB (2000) turut menjelaskan mengenai terma PKMI iaitu kandungan dan pembentangan. Kandungan PKMI merujuk kepada pelbagai maklumat korporat dan maklumat prestasi. Maklumat korporat merangkumi sebahagian atau keseluruhan laporan tahunan. Manakala, maklumat prestasi merujuk kepada maklumat yang tidak termasuk dalam laporan tahunan seperti dalam bahan seperti siaran akhbar atau dalam apa bentuk sumber yang lain. Pembentangan pula merujuk kepada laporan tahunan yang disediakan dalam laman web syarikat dengan menggunakan format HTML atau teknologi Adobe Acrobat. Dalam kata lain, pembentangan merujuk kepada laporan tahunan yang boleh dilayari di laman web syarikat dalam format yang tidak terdapat dalam paradigma kertas (contohnya hiperpaut, grafik animasi, interaktif, lembaran muat turun dan sebagainya).

Debreceny et al. (2002) mengadaptasikan kerangka kerja FASB (2000) bagi mengklasifikasikan dimensi kandungan PKMI (PKMI-K) dan pembentangan PKMI (PKMI-P) seperti dalam Rajah 1. Menurut FASB (2000), dari segi kandungan, laman web boleh memasukkan semua 
kandungan bahan yang diterbitkan oleh sesebuah syarikat dalam bentuk kertas serta ringkasan kandungan, atau kandungan tambahan. Manakala, dari segi pembentangan, laman web boleh menyamai bentuk yang dilaporkan berasaskan kertas iaitu teks dan grafik berbentuk statik (FASB, 2000) dan yang berbentuk dinamik yang tidak dapat digunakan dalam paradigma berasaskan kertas seperti suara dan video (FASB, 2000).

\begin{tabular}{|c|c|c|}
\hline Skor & PKMI-P & PKMI-K \\
\hline 0 & & $\begin{array}{l}\text { Maklumat kewangan lengkap dan maklumat } \\
\text { tambahan yang boleh dimuat turun dan/atau } \\
\text { HTML }\end{array}$ \\
\hline 1 & Dinamik & $\begin{array}{l}\text { Maklumat kewangan lengkap yang boleh dimuat } \\
\text { turun dan/atau HTML }\end{array}$ \\
\hline 2 & Statik & $\begin{array}{l}\text { Ringkasan maklumat kewangan yang boleh } \\
\text { dimuat turun dan/atau HTML }\end{array}$ \\
\hline 3 & Tiada laman web & Tiada PKMI \\
\hline
\end{tabular}

Sumber: Debreceny et al. (2002)

Rajah 1: Skima Pengukuran PKMI-K dan PKMI-P

Menurut Debreceny et al. (2002) seperti merujuk kepada FASB (2000, p. 30), kandungan bagi PKMI dikelaskan kepada empat kategori: (1) tiada maklumat kewangan yang dilaporkan dalam laman web, (2) kandungan ringkas iaitu pelaporan dalam laman web kurang daripada apa yang dibentangkan dalam laporan tahunan berasaskan kertas, (3) kandungan penuh iaitu laman web dan laporan tahunan berasaskan kertas memberikan pelaporan yang setara, dan (4) kandungan lebih iaitu laman web memberikan pendedahan yang melebihi apa yang ada dalam laporan tahunan berasaskan kertas. Manakala, pembentangan bagi PKMI dikelaskan kepada tiga kategori: (1) tiada laman web, (2) pembentangan statik iaitu pembentangan laman web sama seperti apa yang ada di dalam laporan tahunan berasaskan kertas termasuk teks dan grafik statik, dan (3) pembentangan dinamik iaitu teknik yang digunakan tidak boleh digunakan dalam paradigma kertas termasuk bentuk seperti lawatan hyperlinked, suara, video, interaktif pangkalan data dan sebagainya.

Penerangan bagi dimensi (kandungan, pemasaan, teknologi dan sokongan pengguna) dijelaskan dalam Jadual 3. Manakala, Chan dan Wickramasinghe (2006) memasuk dan menyemak semula kriteria yang bersifat subjektif di dalam penentuan kriteria sistem penskoran indeks pelaporan. Chan dan Wickramasinghe (2006) juga memasukkan kriteria baru bagi mengambarkan paparan laman web terkini. Penerangan lanjutan mengenai sistem penskoran kriteria dijelaskan dalam Jadual 4. 
Jadual 3: Maklumat Kriteria

\begin{tabular}{cl}
\hline Dimensi & \multicolumn{1}{c}{ Kriteria Pengukuran } \\
\hline \multirow{2}{*}{ Kandungan } & $\begin{array}{l}\text { Mengukur jenis maklumat kewangan yang diterbitkan, termasuklah } \\
\text { ketersediaan penyata kewangan syarikat, penyata interim dan maklumat } \\
\text { period sebelumnya }\end{array}$ \\
Pemasaan & $\begin{array}{l}\text { Mengukur ketepatan masa bagi maklumat kewangan yang disediakan, } \\
\text { termasuklah ketersediaan siaran akhbar atau maklumat harga saham }\end{array}$ \\
Teknologi & $\begin{array}{l}\text { Mengukur sejauh mana sesebuah syarikat mengunakan paparan teknologi } \\
\text { terkini seperti gambar bergerak, grafik, hiperpautan, enjin pencarian dan } \\
\text { muat turun data atau senarai mel }\end{array}$ \\
Sokongan & $\begin{array}{l}\text { Mengukur reka bentuk dan susun atur laman web, ketepatan } \\
\text { pembentangan, masa yang diperlukan untuk mencapai laman web dan } \\
\text { bilangan klik yang diperlukan bagi mencapai maklumat tertentu }\end{array}$ \\
\hline
\end{tabular}

Sumber: Pirchegger dan Wagenhofer (1999).

Jadual 4: Penskoran Kriteria

\begin{tabular}{cl}
\hline Dimensi & \multicolumn{1}{c}{ Kriteria Pengukuran } \\
\hline \multirow{3}{*}{ Kandungan } & $\begin{array}{l}\text { Sejauh mana maklumat kewangan boleh diperoleh menerusi Internet } \\
\text { termasuklah laporan tahunan dan ringkasan kewangan, maklumat } \\
\text { pemegang saham, pengagihan pemegang saham dan glosari. Petunjuk } \\
\text { mengenai maklumat diaudit dan tidak diaudit turut diambil kira } \\
\text { terutamanya laporan setengah tahun dan laporan sukuan }\end{array}$ \\
Pemasaan & $\begin{array}{l}\text { Mengukur ketepatan masa bagi maklumat kewangan yang disediakan, } \\
\text { termasuklah berapa kerap harga saham dikemas kini }\end{array}$ \\
Teknologi & $\begin{array}{l}\text { Mengukur sejauh mana sesebuah syarikat mengunakan paparan teknologi } \\
\text { terkini seperti gambar bergerak, hiperpautan teks, maklum balas e-mail, } \\
\text { rangkaian dalaman, fail suara dan persembahan video }\end{array}$ \\
& $\begin{array}{l}\text { Mengukur sejauh mana sokongan pengguna ditawarkan oleh laman } \\
\text { web termasuklah format muat turun, pilihan warna dalam muat turun } \\
\text { dokumen, keupayaan muat turun laporan tahunan yang lengkap, } \\
\text { kalkulator pelaburan, servis pemegang saham dalam talian, analisis } \\
\text { Pengguna } \\
\text { saham dan pengumuman awam }\end{array}$ \\
\hline
\end{tabular}

Sumber: Chan dan Wickramasinghe (2006).

Secara keseluruhan, pelbagai dimensi telah digunakan bagi menggambarkan indeks PKMI. Hasil tinjauan menunjukkan bahawa tiada penekanan yang jelas terhadap dimensi yang khusus bagi PKMI dalam kalangan penyelidik. Bagaimanapun, kebanyakan penyelidik memasukkan dimensi yang berkaitan dengan kandungan, pemasaan, teknologi dan sokongan pengguna (Pirchegger \& Wagenhofer, 1999; 
Lybaert, 2002; Davey \& Homkajohn, 2004; Chan \& Wickramasinghe, 2006), diikuti dengan dimensi kandungan dan pembentangan (IASC, 1999; Debreceny et al., 2002; Marston \& Polei, 2004; Trabelsi et al., 2004; Xiao et al., 2004; Spanos, 2006; Bonson \& Escobar, 2006). Keadaan ini berkemungkinan disebabkan PKMI adalah berasaskan pendedahan secara sukarela.

Oleh kerana maklumat yang dilaporkan menerusi Internet memberi nilai yang berbeza-beza, Ettredge et al. (2001a) mencadangkan supaya penyelidik menggunakan nilai pemberat untuk mengukur kuantiti maklumat yang diterbitkan menerusi Internet. Sebagai contoh, penyelidik boleh memberi skor 2 bagi laporan tahunan yang lengkap dan skor 1 bagi sebahagian laporan. Malahan, Marston dan Shrives (1991) menjelaskan bahawa sekiranya terdapat bilangan item yang banyak di dalam sesuatu indeks ia menjangkakan skor wajaran dan skor bukan wajaran akan memberikan jawapan yang sama. Dengan kata lain, sampel syarikat akan memberikan keutamaan dengan memberikan jawapan yang sama pada indeks pelaporan sama ada menggunakan skor wajaran atau skor bukan wajaran. Bagaimanapun, bagi mereka yang mempertahankan kegunaan skor wajaran berpendapat bahawa pemberat tidak mengubah keputusan secara signifikan (Chow \& Woren-Boren, 1987; Wallace \& Naser, 1995). Tambahan lagi, bukti empirikal (Spero, 1979; Robbins \& Austin, 1986; Chow \& Wong-Boren, 1987) ada mencadangkan supaya skor wajaran dan skor bukan wajaran dapat ditukar kerana hasilnya memberikan keputusan yang sama. Selain itu, Adhikari dan Tondkar (1992) dan Firth (1980) turut menyatakan bahawa skor wajaran dan skor bukan wajaran menunjukkan dapatan keputusan yang sama.

Kerangka kerja penyelidikan bagi cadangan indeks pelaporan yang komprehensif adalah berasaskan sorotan literatur yang meluas (IASC, 1999; Debreceny et al., 2002; Marston \& Polei, 2004; Trabelsi et al., 2004; Xiao et al., 2004; Spanos, 2006; Bonson \& Escobar, 2006) dengan indeks pelaporan digunakan untuk mengukur kualiti laman web syarikat. Berikutan itu, penulis berpendapat bahawa dimensi berasaskan kandungan dan pembentangan sesuai digunakan untuk mengetahui tahap PKMI atas beberapa alasan. Pertamanya, dimensi kandungan dan pembentangan adalah dimensi yang paling popular dan diterima oleh ramai pengkaji (IASC, 1999; Debreceny et al., 2002; Marston \& Polei, 2004; Trabelsi et al., 2004; Xiao et al., 2004; Spanos, 2006; Bonson \& Escobar, 2006) untuk mengukur kualiti laman web syarikat. Kedua, kajian 
terdahulu menunjukkan bahawa format kandungan dan pembentangan bagi pelaporan Internet boleh memperbaiki ketelusan pelaporan (Hodge et al., 2004; Kelton \& Yang, 2005). Ketiga, PKMI membenarkan penyebaran alternatif bagi jenis pelaporan yang tidak diperlukan oleh badan berperaturan (regulatory bodies) (Ettredge et al., 2002). Malahan, format pembentangan boleh menyediakan pelaporan yang lebih telus melalui peningkatan kebolehbacaan, mudah diperoleh, mudah difahami bagi maklumat kewangan (FASB, 2000), membantu memperoleh maklumat dengan cepat serta disokong dengan penggunaan ciri paparan yang bersifat mesra pengguna dalam laman web (Marston \& Polei, 2004), berurusan dengan bagaimana maklumat itu dipersembahkan (Xiao et al., 2004), dan boleh memperbaiki ketepatan masa (peningkatan dalam kekerapan pendedahan) dan pengesahan (berupaya untuk menghubungkan dengan pelbagai sumber maklumat lain seperti hiperpautan) (Debreceny et al., 2002). Manakala, format kandungan boleh menunjukkan jenis maklumat yang dilaporkan oleh syarikat menerusi laman web (Lybaert, 2002; Xiao et al., 2004).

Berdasarkan kepada perbincangan sebelum ini, penulis berpendapat bahawa dimensi kandungan dan pembentangan merupakan dimensi yang paling sesuai digunakan bagi menggambarkan tahap PKMI seperti yang diperjelaskan menerusi Jadual 5 dan Rajah 2 di bawah. Seterusnya, penulis turut memberi contoh beberapa item bagaimana skor diberikan bagi setiap dimensi seperti di Jadual 6. Selain itu, penulis menyarankan penggunaan skor bukan wajaran kerana dapatan kajian bagi indeks pelaporan bukan wajaran dan indeks pelaporan wajaran menunjukkan keputusan yang sama (Spero, 1979; Firth, 1980; Robbins \& Austin, 1986; Chow \& Woren-Boren, 1987; Adhikari \& Tondkar, 1992; Wallace \& Naser, 1995).

Jadual 5: Penskoran Kriteria Dimensi bagi Tahap PKMI

Dimensi

Kriteria Pengukuran

$\begin{array}{ll}\text { Kandungan } & \begin{array}{l}\text { Mengukur tahap maklumat kewangan boleh diperoleh } \\ \text { menerusi Internet }\end{array} \\ \text { Pembentangan } & \begin{array}{l}\text { Mengukur tahap sesebuah syarikat menggunakan } \\ \text { paparan teknologi terkini dan sokongan pengguna yang } \\ \text { ditawarkan oleh laman web }\end{array}\end{array}$

IJMS 16 (1), 75-96 (2009) 


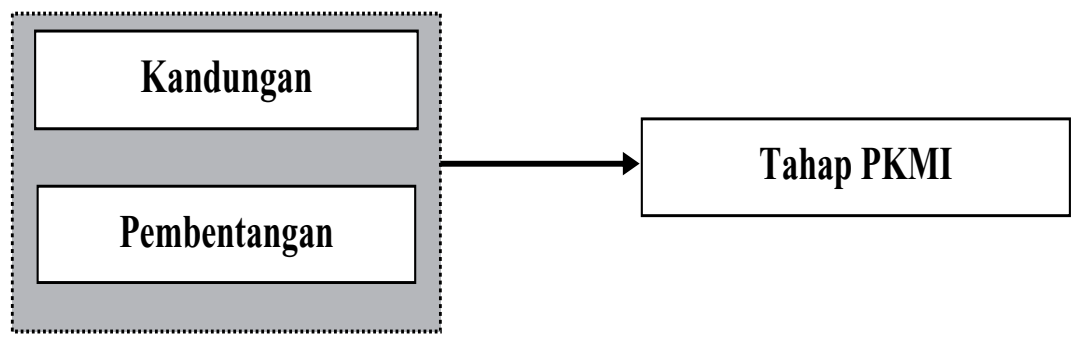

Rajah 2: Dimensi pengukuran tahap PKMI

Jadual 6: Contoh Penskoran bagi Cadangan Dimensi

Dimensi

Keterangan Pengoperasian

Kandungan

Bagi mengukur jenis maklumat kewangan yang diterbitkan menerusi Internet, berikut antara beberapa contoh item;

Skor 1 jika laman web menyediakan keseluruhan laporan tahunan, dan skor 0 sebaliknya.

Skor 1 jika laman web menyediakan kunci kira-kira disatukan, dan skor 0 sebaliknya.

Skor 1 jika laman web menyediakan penyata pendapatan disatukan, dan skor 0 sebaliknya.

Skor 1 jika laman web menyediakan penyata aliran tunai disatukan, dan skor 0 sebaliknya.

Skor 1 jika laman web menyediakan penyata perubahan ekuiti disatukan, dan skor 0 sebaliknya.

Skor 1 jika laman web menyediakan nota-nota kepada penyata kewangan, dan skor 0 sebaliknya.

Bagi mengukur tahap sesebuah syarikat menggunakan paparan teknologi terkini dan sokongan pengguna yang ditawarkan oleh laman web, berikut antara beberapa contoh item;

Skor 1 jika laman web yang lengkap di paparan skrin dalam tempoh 10 saat, dan skor 0 sebaliknya.

Skor 1 jika laman web menyediakan fail yang mempunyai suara dan pembentangan video dan skor 0 sebaliknya.

Pembentangan Skor 1 jika laman web menyediakan senarai mel, dan skor 0 sebaliknya.

Skor 1 jika laman web boleh muat turun maklumat kewangan, dan skor 0 sebaliknya.

Skor 1 jika laman web menyediakan data kewangan dalam format html atau format pemprosesan, dan skor 0 sebaliknya. 


\section{KESIMPULAN}

Bagi mengkaji hubungan antara kriteria firma dengan tingkah laku korporat, indeks pelaporan dibentuk dan dipertimbangkan sebagai alat penyelidikan yang penting (Marston \& Shrives, 1991; Celik et al., 2006). Bertitik tolak dari tahun 1990-an sehingga kini, indeks pelaporan sering dijadikan medan penyelidikan oleh ramai penyelidik untuk mengkaji tahap PKMI. Namun begitu, hasil daripada sorotan literatur jelas menunjukkan pembentukan indeks pelaporan bukannya suatu yang mudah kerana melibatkan unsur penilaian secara subjektif (Marston \& Shrives, 1991).

Oleh yang demikian, perbincangan dalam artikel ini mengutarakan agenda penyelidikan yang penting pada masa hadapan iaitu penggunaan dimensi kandungan dan pembentangan bagi mengetahui tahap PKMI. Berasaskan penelitian terhadap karya lepas secara meluas dan teliti, bolehlah dirumuskan bahawa indeks pelaporan yang lebih komprehensif dan holistik diperlukan dengan mengambil kira dimensi yang relevan. Dimensi kandungan akan memberikan maklumat mengenai jenis maklumat yang didedahkan oleh syarikat menerusi laman web. Manakala, dimensi pembentangan akan memberikan maklumat mengenai penggunaan ciri paparan terkini dalam menyebarkan maklumat korporat dan reka bentuk laman web sesebuah syarikat.

Kesimpulannya, diharapkan penggunaan dimensi kandungan dan pembentangan dapat dimanfaatkan dalam rangka untuk mengetahui tahap PKMI. Seterusnya, penggunaan indeks pelaporan bukan wajaran akan dapat menentukan tahap PKMI sesebuah syarikat. Cadangan penggunaan dimensi kandungan dan pembentangan serta indeks pelaporan bukan wajaran diharap akan dapat memberi jalan penyelesaian kepada penggunaan dimensi yang tidak konsisten dan indeks pelaporan dalam hal yang berkaitan dengan penyelidikan PKMI.

\section{PENGHARGAAN}

Penulis ingin merakamkan ucapan terima kasih terutama kepada Prof. Dr. Abdul Ghafar Ismail dan Prof. Dr. Loo Ern Chen di atas pandangan yang membina semasa sesi pembentangan Doctoral Consortium di Accounting Studies International Conference (ASIC) 2007 di Crown Princess Hotel, Kuala Lumpur pada 31 Oktober 2007 anjuran Fakulti Perakaunan, Universiti Utara Malaysia, Sintok, Kedah Darul Aman. 
Penulis turut merakamkan ribuan terima kasih atas pandangan dan maklum balas daripada semua peserta di $3^{r d}$ Post Graduate Seminar FPPSM di Universiti Teknologi Malaysia (UTM) pada 8 September 2007 anjuran Fakulti Pengurusan dan Pembangunan Sumber Manusia (FPPSM), UTM, Skudai, Johor Darul Ta'zim. Penulis turut mengucapkan ribuan terima kasih kepada Pn. Norhayati bte Hj. Salleh dan En. Mohd. Azhar bin Abd. Hamid di atas pengeditan artikel ini.

\section{RUJUKAN}

Adhikari, A., \& Tondkar, R.H. (1992). Environmental factors influencing accounting disclosure requirements of global stock exchanges. Journal of International Financial Management and Accounting, 4(2), 75-105.

Allam, A., \& Lymer, A. (2003). Development in Internet financial reporting: Review and analysis across five developed countries. The International Journal of Digital Accounting Research, 3(6), 165-199.

Ashbaugh, H., Johnstone, K.M., \& Warfield, T.D. (1999). Corporate reporting on the Internet. Accounting Horizons, 13(3), 241-257.

Beattie, V., \& Pratt, K. (2001). Business reporting: Harnessing the power of the internet for users. Institute of Chartered Accountants of Scotland Research Report.

Bonson, E., \& Escobar, T. (2006). Digital reporting in Eastern European: An empirical study. International Journal of Accounting Information System, 7, 299-318.

Celik, O., Ecer, A., \& Karabacak, H. (2006). Impact of firm specific characteristics on the web based business reporting: Evidence from the companies listed in Turkey. Problems and Perspectives in Management, 4(3), 100-133.

Chan, W.K., \& Wickramasinghe, N. (2006). Using the internet for financial disclosure: The Australian experince. International Journal Electronic Finance, 2(1), 118-150.

Chow, C.W., \& Wong-Boren, A. (1987). Voluntary financial disclosure by Mexican corporations. Accounting Review, 62(3), 533-541.

CICA. (1999). The Impact of Technology on Financial and Business Reporting. Research study for the Canadian Institute of Chartered Accountants.

Craven, B.M., \& Marston, C.L. (1999). Financial reporting on the internet by leading UK companies. The European Accounting Review, 8(2), 321-333.

Davey, H., \& Hamkajohn, K. (2004). Corporate Internet reporting: An Asian example. Problems and Perpectives in Management, 2, 211-227. 
Debreceny, R., Gray, G.L., \& Rahman, A. (2002). The determinants of Internet financial reporting. Journal of Accounting and Public Policy, 21( 4-5), 371-394.

Deller, D., Stubenrath, M., \& Weber, C. (1999). A Survey on the use of the internet for investor relations in the USA, the UK and Germany. The European Accounting Review, 8(2), 351-364.

Ettredge, M., Richardson, V.J., \& Scholz, S. (2001a). The presentation of financial information at corporate Web sites. International Journal of Accounting Information Systems, 2, 149-168.

Ettredge, M., Richardson, V.J., \& Scholz, S. (2001b). A web site design model for financial information. Communications of the $A C M$, 44(11), 51-55.

Ettredge, M., Richardson, V.J., \& Scholz, S. (2002). Dissemination of information for investors at corporate Web sites. Journal of Accounting and Public Policy, 21, 357-369.

FASB. (2000). Business reporting research project: Electronic distribution of business reporting information. Steering Committee Report Series. Financial Accounting Standards Board.

FASB. (2001). Improving business reporting: Insights into enhancing voluntary disclosures. Financial Accounting Standards Board.

Fathilatul Zakimi Abdul Hamid, \& Md Suhaimi Md Salleh. (2005). The Determinants of the Investor Relations Information in the Malaysian Companies' Website. Corporate Ownership \& Control, 3(1), 173-185.

Firth, M. (1980). Raising finance and firms' corporate reporting policies. Abacus, June, 100-115.

Flynn, G., \& Gowthorpe, C. (1997, July) Volunteering financial data on the world wide web. A study of financial reporting from a stakeholder perspective. Paper presented at the 1st Financial Reporting and Business Communication Conference, Cardiff, $3 / 4$.

Gowthorpe, C. (2000). Corporate reporting on the internet: Developing opportunities for research. The Journal of Applied Accounting Research, 5(3), 3-29.

Gray, G.L., \& Debreceny, R. (1997). Corporate reporting on the Internet: Opportunities and challenges. Paper presented at the Seventh Asian-Pacific Conference on International Accounting Issues, Bangkok.

Healy, P.M., \& Palepu, K.G. (2001). Information asymmetry, corporate disclosure, and the capital market: A review of the empirical disclosure literature. Journal of Accounting and Economics, 31, 405440.

Hedlin, P. (1999). The internet as a vehicle for investor relations: The Swedish case. The European Accounting Review, 8(2), 373-381. 
Hodge, F.D. (2001). Hyperlinking unaudited information to audited financial statements: Effects on investor judgements. The Accounting Review, 76(4), 675-691.

Hodge, F.D., Kennedy, J.J., \& Maines, L.A. (2004). Does search facilating technology improve the transparency of financial repoting? The Accounting Review, 79(3), 687-703.

IASC. (1999). IASC Publishers study of business reporting on the internet. Press Release: International Accounting Standards Committee, 15 November 1999.

ICAEW. (1998). The 21st century annual reporting. London. The Institute of Chartered Accountants in Englands and Wales.

ICAEW. (2004). Digital reporting: A progress report. London. The Institute of Chartered Accountants in Englands and Wales.

Kelton, A., \& Yang, Y. (2005). The impact of corporate governance on Internet financial reporting. Working Paper, Department of Accounting and Information Management, University of Tennessee.

Khadaroo, M.I. (2005). Business reporting on the internet in Malaysia and Singapore: A comparative study. Corporate Communications: An International Journal, 10(1), 58-68.

Khan, T. (2006). Financial reporting disclosure on the internet: An international perspective. Unpublished doctoral dissertation, Victoria University, Footscray Park, Victoria, Australia.

Lee, J. (1987). Accounting infrastructure and economic development. Journal of Accounting and Public Policy, 6, 75-85.

Lodhia, S.K., Allam, A., \& Lymer, A. (2004). Corporate Reporting on the Internet in Australia: An Exploratory Study. Australian Accounting Review, 14(3), 64-71.

Louwers, T.W., Pasewark, W., \& Typpo, E. (1996). Silicon valley meets Norwalk. Journal of Accountancy, 186, 20-24.

Lybaert, N. (2002). On-line financial reporting: An analysis of the dutch listed firms. The International Journal of Digital Accounting Research, 2(4), 195-234.

Lymer, A., \& Tallberg, A. (1997, April). Corporate reporting and the internetA survey and commentary on the use of the WWW in corporate reporting in the UK and Finland. Paper presented at the Annual Congress of the European Accounting Congress, Graz, Austria.

Lymer, A. (1997). The use of the Internet for corporate reporting - A discussion of the issues and survey of current usage in the UK. Journal of Financial Information Systems. Retrieved March 3, 1999, from http://www.shu.ac.uk/school/fsl/fisjnl//voll996/ pprs1997/ lymer97.htm

Lymer, A. (1999). The Internet and the future of corporate reporting in Europe. European Accounting Review, 2(2), 289-301. 
Lymer, A., Debreceny, R., Gray, G.L., \& Rahman, A. (1999). Business reporting on the internet. IASC Research Report.

Marston, C., \& Leow, C.Y. (1998), Financial reporting on the Internet by leading UK companies. Paper presented at the $21^{\text {st }}$ Annual Congress of the European Accounting Association, Antwerp, Belgium.

Marston, C., \& Polei, A. (2004). Corporate reporting on the internet by German companies. International Journal of Accounting Information System, 5, 285-311.

Marston, C.L., \& Shrives, P.J. (1991). The use of disclosure indices in accounting research: A review article. British Accounting Review, 23, 195-210.

Mendes-da-Silva, W., \& Christensen, T.E. (2004, August). Determinants of voluntary disclosure of financial information on the internet by brazilian firms.

Mohamed Hisham Haniffa, \& Hafiz-Majdi Ab. Rashid. (2005). The determinants of voluntary disclosures in Malaysia: The case of internet financial reporting. UNITAR E-Journal, 2(1), 22-42.

Mokhtar, A.B., \& Azhari, A.R.H. (2004). Perkembangan sistem perbankan Islam di Malaysia: Kajian dari sudut Strategi Penyebaran Maklumat menerusi Laman Web. The Journal of Muamalat and Islamic Finance Research, 1(1), 191-207.

Momany, M.T., \& Al-Shorman, S.A. (2006). Web-based voluntary financial reporting of Jordanian companies. International Review of Business Research Papers, 2(2), 127-139.

Oyelere, P., Laswad, F., \& Fisher, R. (2003). Determinants of internet financial reporting by New Zealand companies. Journal of International Financial Management and Accounting, 14(1), 26-61.

Pervan, I. (2006). Voluntary financial reporting on the internet- analysis of the practice of stock-market listed crotian and slovene joint stock companies. Financial Theory and Practice, 30(1), 1-27.

Petravick, S., \& Gillett, J. (1996, July). Financial reporting on the world wide web. Management Accounting, 26-29.

Petravick, S., \& Gillett, J. (1998, October). Distributing earnings reports on the internet. Management Accounting, 54-56.

Pirchegger, B., \& Wagenhofer, A. (1999). Financial information on the Internet: A survey of the homepages of Austrian companies. The European Accounting Review, 8(2), 383-395.

Robbins, W.A., \& Austin, D.R. (1986). Disclosure quality in governmental financial reports: An assessment of the appropriateness of a compound measure. Journal of Accounting Research, 24(2), 412-421.

Rosli Mohamad, Mudzamir Mohamed, \& Amdan Mohamed. (2003). Internet financial reporting (IFR) in Malaysia: A Survey of contents 
and presentations. Paper presented at Accounting Seminar 2003, Putra Palace, Kangar, Perlis, December 8-10, 2003.

Saudagaran, S.M., \& Diga, J. (1997). Financial reporting in emerging capital markets: Characteristics and policy issues. Accounting Horizons, 11(2), 41-64.

Spanos, L. (2006, June). Corporate reporting on the internet in a European emerging capital market: The Greek case.

Spero, L.L. (1979). The extent and causes of voluntary disclosure of financial information in three European capital markets: An exploratory study. Unpublished doctoral dissertation, Harvard University Graduate School of Business.

Sriram, R.S., \& Laksmana, I. (2006). Corporate web site reports: Some evidence on relevance and usefulness. Information Resources Management Journal, 19(3), 1-17.

Trabelsi, S., Labelle, R., \& Laurin, C. (2004). CAP forum on e-business: The management of financial disclosure on corporate websites: A conceptual model. Canada Accounting Perspectives, 3(2), 235-259.

Trites, G. (1999). The impact of technology on financial and business reporting. Canadian Institute of Chartered Accountants.

Wallace, R.S.O., \& Naser, K. (1995). Firm-specific determinants of the comprehensiveness of mandatory disclosure in the annual corporate reports of firms listed on the stock exchange of Hong Kong. Journal of Accounting and Public Policy, 14, 311-369.

William, S.M., \& Pei, C.H.W. (1999). Corporate social disclosure by listed companies on their web sites: An international comparison. The International Journal of Accounting, 34(3), 389-419.

Xiao, J.Z., Jones, M.J., \& Lymer, A. (2002). Immediate trends in Internet reporting. European Accounting Review, 11(2), 245-276.

Xiao, J.Z., Yang, H., \& Chow, C.W. (2004). The determinants and characteristics of voluntary Internet-based disclosures by listed Chinese companies. Journal of Accounting and Public Policy, 23, 191225. 